\title{
Chapter 1 \\ Multiple Paths to Industrialization: \\ A Global Context of the Rise of Emerging \\ States
}

\author{
Kaoru Sugihara
}

\subsection{Introduction}

This volume addresses the issue of how a country, which was incorporated into the world economy as a periphery, could create a path of economic development and industrialization as the 'emerging state' in Asia and Africa. We offer historical and contemporary case studies of development paths, as well as the international background under which a transition to the emerging state was successfully made, delayed or failed.

In this chapter I describe how diverse paths of economic development emerged in various regions of the world, and show that interactions of such 'multiple paths', rather than the diffusion of modern technology and institutions from Western Europe to the rest of the world, determined the timing and pace of global industrialization over the last two centuries. The industrial revolution in England, which began in the late eighteenth century, was first transmitted to Continental Europe, the United States and Japan in the 'long' nineteenth century. During the period of interwar instability and after World War II, a variety of state-led industrialization programs, including socialist models, were implemented, which had varying degrees of success. The diffusion of industrialization has been often interpreted along the Gerschenkronean framework of 'advantage of backwardness' and late development (Gerschenkron 1962; Austin 2013, 288-90). In a broad sense, any state engaged in 'catching-up' industrialization qualifies the emerging state. Thus the first type of the emerging state exploits its respective factor endowment advantages in relation to the more advanced countries. If an Asian country such as Japan is labour abundant and capital scarce, she might focus on the development of labour-intensive industries, in addition to fostering capital-intensive ones for political and military reasons.

\section{K. Sugihara $(\bowtie)$}

Research Institute for Humanity and Nature, Kyoto, Japan

e-mail: sugihara@chikyu.ac.jp 
Meanwhile, as early development economists such as W. A. Lewis pointed out, many countries of Asia and Africa under colonial rule or domination were not given the chance to industrialize, either because industrialized West sought an international division of labour where the latter specialized in manufactured goods while the former was encouraged to specialize in primary products, or, perhaps more fundamentally, because resource and environmental constraints in Asia and Africa, especially their tropical parts, made it difficult for their people to raise agricultural productivity, thus depressing the chance to increase the real wage and the opportunity to train labour (Lewis 1954, 1970).

Another, somewhat related line of development was the state-led, importsubstitution industrialization strategy, pursued in India and China among others, which aimed at political and economic independence at the cost of seeking gains from international trade and technological transfer from advanced countries, especially the United States. The idea of 'import-substitution' was widely shared among the leaders of newly independent states, crossing over the political division between non-allied and socialist countries, which reflected their experiences as a 'periphery' and the impact of 'forced' free trade. In general, this form of 'third world industrialization' and 'state-led development' did not successfully close the gap between the 'North' and the 'South' in terms of per capita GDP or living standards. Nor was it often associated with democracy. But in all cases the state played a powerful role in determining the type of industrialization with varied implications for economic growth and living standards. Industrialization of China in the Mao period, in spite of its stormy politics, left a particularly lasting impression for the study of the role of the state in economic development, not least because it contributed to the improvement of health and education of a very large number of people. Thus the second type of the emerging state as a driver of industrialization came out of the ideology of politico-economic independence and import-substitution, rather than as a result of the exploitation of factor endowment advantages.

A major change came from the western rim of the Pacific in the post-war period. In contrast to Japan's late development since the Meiji period, which we term labourintensive industrialization and categorize as the first type of the emerging state, the Japanese high economic growth in the 1950s and the 1960s resulted in a rapid convergence of per capita GDP to advanced western countries. This could be seen as an extension of pre-war labour-intensive industrialization to a large extent in that its comparative advantage remained firmly in relatively cheap, competitive labour. Newly Industrializing Economies (NIEs) and some Southeast Asian countries adopted the strategy of export-oriented industrialization also by taking advantage of cheap, competitive labour and by meeting the demand from the mass-consumer markets of advanced countries (Sugihara 2013). Then, some states, such as Japan, South Korea and Taiwan, also began to take on the task of creating competitive capital- and resource-intensive industries, and successfully pursued them. This is 'developmentalism', which relies the legitimacy of its existence on growth, willing to go beyond the simple pursuit for exploiting its factor endowment advantages. The state could exercise power to promote industrial technology, build infrastructure and mobilize human and natural resources by prioritizing growth over democracy, equality and 
environmental concerns. ${ }^{1}$ The 'developmental state' with commitment to international trade and growth ideology thus constitutes the third type of the emerging state. It is worth noting that this regional development occurred when mainland China and India were largely outside the orbit of the international economy.

Set against the high economic growth at the western rim of the Pacific, China and India made policy changes around 1979 and 1991 respectively, to re-enter the international economy. There too a fusion between capital-intensive and labour-intensive paths took place, that is, emphasis on capital-intensive, heavy industries (represented by steel and machinery sectors) was eventually replaced by or absorbed into the industrialization strategy with attention to a greater range of industries, including those which were more employment-generating and human-capital-intensive. Thus the growth of the Asia-Pacific economy and regional integration accelerated, and led global industrialization. By the end of the twentieth century the majority of world population lived in industrialized or rapidly industrializing countries, especially in Asia. It is now spreading to the rest of the world. Some emerging economies have built their economy on resource exports and trade, while some states lack the experience of centralized administration. But global industrialization emerged as a formidable force, both as an economic competition and as an ideology, regardless of the preparedness of each developing country. It is this global process of transition that provides the economic context of the rise of emerging states today.

Is there any theory that can explain the timing, pace and underlying causes of this process? This chapter suggests that the key to answering this question lies in the examination of the ways in which regional trade, long distance trade and technology transfer successively released local and regional resource constraints in various parts of the world. Local and regional resource constraints, such as shortage of land, scarcity of water and the lack of access to biomass energy, would reduce the chance for securing food and other necessities, hence a sustainable path of economic development. Intercontinental trade may provide export outlets, while advanced countries could provide technology, capital and human resources, to build an infrastructure and offer advice on policy. From the point of view of a developing country, however, imported resources had to find matching local ones to make economic sense. Earnings from primary exports had to be translated into securing livelihood goods, which normally meant securing supplies locally or through regional trade. Intra-regional trade could mitigate local resource constraints at a critical moment (think of famines). Likewise, modern technology and institutions had to be adapted to the local context of production and consumption. Machinery and means of transport had to adapt to local factor endowment conditions and the effective use of traditional technology and resources (When necessary, the material for the frame of the power-loom, made by steel, temporarily went back to wood, while modern factories and railways resorted to the use of timber, instead of coal, for fuel). Above all, the industrialization drive had to be supported by (thus 'embedded' in) the agricultural economy and population; There technology and institutions would change only very slowly. It is the nature and

\footnotetext{
${ }^{1}$ For discussion on the effects of developmentalism and the developmental state on the environment, see Sugihara (2017).
} 
mechanism of these 'multiple paths' to industrialization and the role various kinds of emerging states played in them that need to be understood.

In the next section we describe the emergence of a three-tier international division of labour where capital-intensive industrialization, labour-intensive industrialization and exports of primary products characterized each region, mainly referring to the period up to World War II. In the third section we focus on the growth of intra-Asian trade, to show local and regional agencies for the growth of world economy and trade. It contributed to labour-intensive industrialization, as well as the growth of the export economy of primary products. The fourth section extends the discussion from the pre-war to the post-war period, and comments on the industrialization experiences of East Asia, and Southeast Asia, from the perspective of the region's respective position in the world economy. The final section discusses the role of the emerging state in relation to industrialization and economic development of Sub-Saharan Africa.

\subsection{Emergence of a Three-Tier International Division of Labour}

\subsubsection{The Beginning}

Before 1800, most local agricultural societies in Asia and Europe developed a system of production and reproduction by accepting local resource constraints, imposed by nature. Reflecting a large 'population-carrying capacity' of monsoon Asia (see Sugihara 2017), 66\% of world population is thought to have lived in Asia, and $22 \%$ in Europe in 1820 (Maddison 2009). The fate of many societies was only partially altered or complemented by regional or intercontinental trade, although some societies were affected by the more drastic interventions such as epidemics and violence. In Asia the arrival of knowledge from outside was often not taken advantage of, unless enlightened rulers made it compatible with the technologies and institutions governing local and regional systems. Thus the Malthusian logic prevailed, even in the early modern period when a gradual but sustained expansion of the market occurred in several core regions of the world (Richards 2003). The balance between population and food had to be retained in the long run.

In what ways was this Malthusian trap overcome? In the "European miracle" narrative, technological breakthroughs during the period from the scientific revolution to the industrial revolution have been highlighted, and accompanying institutional developments, especially emergence of the nation state and the regime of private property rights, have been identified as essential conditions for industrialization and economic growth (Jones 1981). Once agricultural productivity rose and coal became available in some places, major resource constraints such as shortage of land and danger of deforestation began to be significantly eased. Cheap coal helped the diffusion of steam engines in modern factories and transport sectors. Overseas expansion aided by the development of navigation and military technologies also helped ease regional 
resource constraints, through the imports of raw materials and food. Pomeranz called such a resource bonanza 'coal and North America' (Pomeranz 2000). By the early nineteenth century the environmental conditions of Western Europe largely ceased to constrain economic growth. By the second half of the nineteenth century intercontinental trade centering on the Atlantic but also involving Asia grew, and formed an international division of labour where Western Europe exported manufactured goods to, and imported primary products from, the rest of the world.

However, this was a solution specific to Western Europe. The ways in which resource constraints were eased in the subsequent process of global industrialization differed region by region (Sugihara 2015a). The level of constraints in the United States and other regions of recent European settlement (such as Canada, Australia and New Zealand) was much lower than that in Western Europe in some crucial measures (such as land and biomass stock), making room for them, especially the United States, to pursue an even more capital- and resource-intensive path than countries in Western Europe. In East Asia, meanwhile, land was much more scarce relative to population, and people were fed, clothed and organized quite differently, mainly through rice farming and associated proto-industry and social institutions. It created the more labour-intensive and eventually resource-saving path (for the socio-ecological foundations for this path, see Oshima 1987). In other words, neither the United States nor East Asia followed the path Western Europe had created. The critical importance of the availability of water, and the frequency of epidemics and natural disasters, especially in the tropical parts of Asia, Africa and Latin America, further signaled the difference of resource endowments of various regions of the world, hence the impossibility of conceptualizing the relationship between industrialization and the environment on the basis of the experience of Western Europe.

\subsubsection{The Western Supremacy and Reorganization of Asian Industries}

Between 1750 and 1840 an overwhelming proportion of world industrial production, mostly un-mechanized, was located in Asia, especially in China and India (see Fig. 1.1). Even in 1840 the impact of mechanized industries was limited. In industrializing Europe a half of textile production was still un-mechanized. By 1910 the world market of textiles was dominated by the modern English cotton textile industry. The decline of traditional industries, especially cotton textile industry in India (and to a lesser extent China), was a serious global event that involved a loss of employment on an unprecedented scale (Bagchi 1976; Roy 2005: 106-15). Asia's share in world GDP declined from $60 \%$ in 1820 to $25 \%$ in 1913, while that of Western Europe rose from 20 to 31\%, and North America from 2 to 20\% in these years (Maddison 2009). This mainly reflected the widening gap in real wages between Asia and the West, although the growth of GDP in North America reflected the rapid growth of migrant population as well. Asia became an importer of English textiles and an exporter 


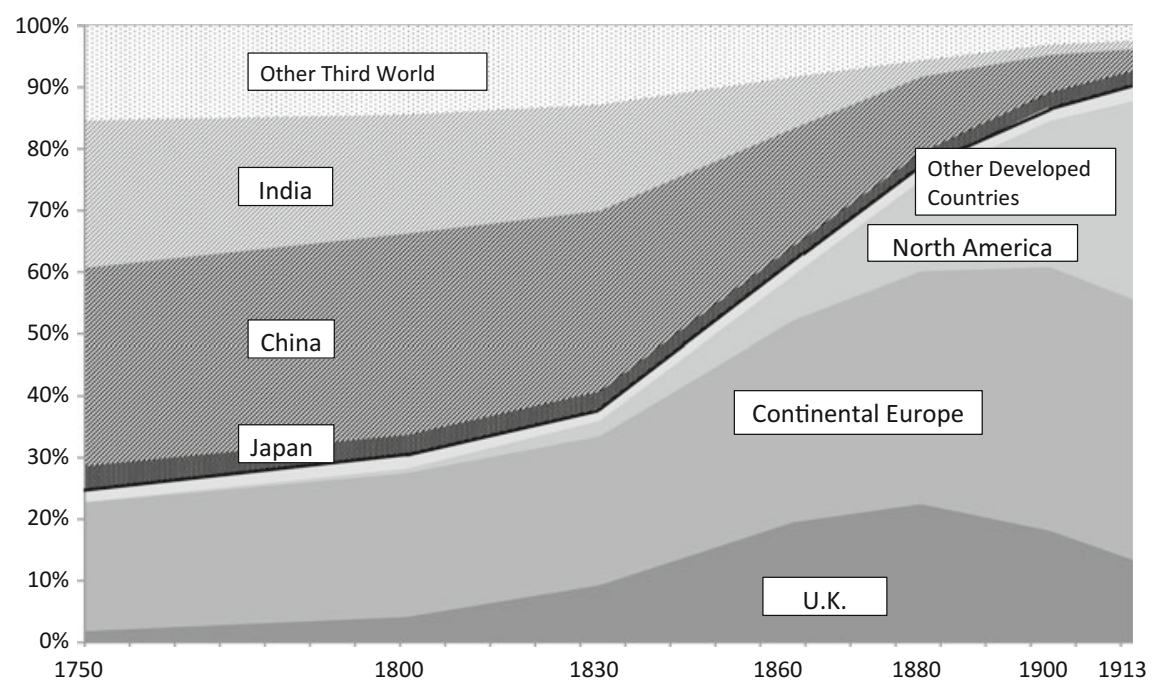

Fig. 1.1 Geographical composition of world industrial production, 1750-1913. Source and Note Bairoch (1982: 292). In Bairoch's overall data Japan is included in 'developed countries', but I reclassified her under 'developing countries', as this Figure refers to the period up to 1913

of tea, rice, sugar, tin, rubber, raw cotton, raw silk, raw jute and wheat. Thus an international division of labour emerged between industrialized West as exporters of manufactured goods, and Asia as exporters of primary products. The environmental implication of this division of labour was the transfer of (mainly land-derived) natural resources from the latter to the former, in exchange for the improvement of transport, urbanization and mass-produced consumer goods. Industrialization in this context has typically been portrayed as an agent of both resource exploitation and the diffusion of modern science and technology.

However, Asia's response to Western impact also contained another feature, namely labour-intensive industrialization. Asia was not just de-industrialized but was reorganized into a new form of industrialization. Thus there were two different routes of diffusion of industrialization, the capital-intensive route originating in the West, and the labour-intensive one originating in the East. In addition, the latter tended to be less resource-intensive than the former. I describe below the emergence of a three-tier international division of labour between capital-intensive manufactured goods, labour-intensive manufactured goods and primary products, and an increasingly uneven global resource allocation in favour of Europe and regions of recent European settlement, in the period from the nineteenth century to the 1930s. I also suggest that this three-tier structure was developed into the main pattern of the international division of labour by the end of the twentieth century.

First, the growth of the Atlantic economy represents the main global route to industrialization in terms of leading technological and institutional developments. Countries in Continental Europe and the regions of recent European settlement achieved 
industrialization by learning new technology and/or by importing capital, labour and machinery with their export earnings. In the New World, the integration of vast natural resources into the international economy served as the engine of economic growth. Labour was scarce and land and other resources were abundant, and the difference in factor endowments between the old and the new worlds induced a growth of trade, migration and investment. In the nineteenth and early twentieth centuries, the growth of the Atlantic economy was prominent in intercontinental trade. An implication of this development was that the regions of recent European settlement had a better incentive than Britain to raise labour productivity, using abundant natural resources and employing imported capital. The movement towards the development of labour-saving, capital-intensive and resource-intensive technology was most clearly observed in the United States (for the significance of different factor endowments behind different institutions within the Americas, see Engerman and Sokoloff 2011). The need to save skilled labour led to standardization of industrial production such as the use of transferable parts, which in turn facilitated the transfer of technology across industries and the development of mass production, as well as 'deskilling' of labour. Industrialization became associated with the exploitation of economies of scale.

The American frontier was exhausted around 1890, and by the early 1920s migration from Europe ceased to be encouraged. But American technology continued to lead the world, by raising labour productivity through automation, the introduction of more systematic labour management and mass marketing. Looking back from the twenty-first century, the British industrial revolution only began to show the explosive power of labour-saving technology through the use of coal and steam engines, and merely paved the way for a fuller replacement of skilled labour by capital and technology. Therefore, although the conditions for the industrial revolution may have been laid in Europe, the 'Western path', with emphasis on capital-intensive and resource-intensive technology, arguably only became fully established as a result of the growth of the Atlantic economy.

As far as the direction of technology and institutions is concerned, the Soviet model of 'big push' resembled the American one, in so far as it was capital- and resource-intensive. In this model emphasis on heavy and chemical industries, and on high-technology sectors backed by the state, was quite explicit. Although some aspects of these industrialization strategies were successful (see Allen 2005), many socialist economies eventually failed to foster internationally competitive industries.

Second, a different model developed in Asia. Although earlier efforts tended to attempt at a direct transfer of Western technology and institutions, the Japanese government by the 1880s had developed an industrialisation strategy quite distinct from such attempts. Recognizing that both land and capital were scarce, while labour was abundant and of relatively good quality, the new strategy was to encourage active use of the tradition of labour-intensive technology, modernisation of traditional industry, and conscious adaptation of Western technology to different conditions of factor endowment. The path Japan developed can be termed 'labour-intensive industrialisation', as it absorbed and utilised labour more fully and depended less on the replacement of labour by machinery and capital than the Western path. Some traditional 
industries not only survived but developed. For example, hand-weaving industry sustained a large employment with the use of machine-made yarn, contributing to the development of a market for mass consumer goods by combining the efficiency of machine made intermediate goods with traditional clothing patterns.

The comparative advantage of labour-intensive industries in Asia was reinforced by the divergence through the growth of real wage gap between the Atlantic highwage economy and the non-European low-wage economies. The persistence of this gap was partly helped by migration laws in the United States and other regions of recent European settlement. A largely unintended consequence of this was that it progressively became easier for Japan, the first industrial nation in Asia, to compete with Western manufacturers in the international market of labour-intensive manufactured goods where wage differences mattered. The difference between the structure of consumption in Asia and the West was another important factor that made it possible for Asia to industrialise itself. Thus industries of Asia and Europe developed, each with separate niches.

Under the imposition of the free trade regime, labour-intensive industrialization constituted the core of Asia's development path, and the expansion of its trade served as an engine of regional industrialization. The rate of growth of intra-Asian trade between 1880 and 1938 was faster than that of Asia's trade with the West or world trade, as the division of labour between agriculture and industry grew at local and regional levels, and merchant networks exploited slight differences in price and quality of commodities, including manufactured goods. Thus, like the Japanese handweavers mentioned above, Chinese hand-weavers used Indian, and later Japanese, machine-made yarn before the modern Chinese spinning industry provided it to them. A substantial proportion of Japanese yarn by this time was made from Indian raw cotton. Thus there developed a competitive international commodity chain within Asia (Sugihara 1996, 2005a). Since most of Asia were labour abundant, successful industrializers needed to possess a pool of competitive labour, that is, cheap labour relative to efficiency. The effort to improve the quality of labour was an important feature of Japan's industrialization, while intra-Asian trade, led by Chinese and Indian merchant networks, was a main mechanism through which massive employment was maintained and the quality of labour was tested at each point of labour absorption.

An important consequence of the emergence of the three-tier international division of labour was that both capital-intensive industrialization and labour-intensive industrialization needed the supplier of primary products. There was a transfer of natural resources from primary producers to industrial countries, especially to those pursuing capital- and resource-intensive industrialization. But those pursuing labourintensive industrialization also exploited natural resources from other parts of Asia and beyond. As we will see in Sect. 1.5, the rapid development of economic relationships between growth Asia and Sub-Saharan Africa suggests that Asia, along with the West, acts as a major importer of natural resources, while retaining a competitive position in the international market of labour-intensive manufactures at the same time. 


\subsection{Intra-regional Trade as an Agent of Economic Development}

\subsubsection{Integration of Asia and Africa into the World Economy}

Figure 1.2 shows that intercontinental trade in 1840 was centred on Western Europe, while there were very large regional trading zones both in Europe and Asia. One of the reasons why my figures on intra-Asian trade (especially rough figures) are so large is that I have included all intra-Asian trade, regardless of whether they are indigenous commodities, imported foreign goods or commercial crops for export. Thus, if English textiles were brought to Bombay or Singapore, and then were redistributed by Indian or Chinese merchants within India or Southeast Asia, we would count the latter transaction as intra-Asian trade. Unless English textiles were consumed within Bombay or Singapore, therefore, most imported goods would be counted as regional trade as well. This is appropriate in my view, as most of the time English or European traders were unable to penetrate into the interior or smaller markets of Asia, and were dependent on the initiatives of Asian merchants for the maintenance of their intercontinental trade. The same points can be made with regard to much of Asia's exports to the West. Peasant producers in the hinterland were most likely to deal with local or regional Asian merchants, who would in turn sell their produce to Western merchants at large ports. Behind the strength of Asian merchants were their extensive local and regional networks, which were developed with the use of their languages and under the influence of their cultures and social institutions. A large difference in the two figures for intra-Asian trade in Figs. 1.2, mainly comes from the inclusion of local trade relating to long-distance trade, and definition of territorial units. The units in Asia at this point was larger than anywhere else in the world.

By 1910 the structure of world trade became much more multilateral (Fig. 1.3). The United States became an important participant, while many primary producers in Latin America, parts of Asia (such as Middle East) and Africa were integrated into the trade structure as a satellite of the metropolitan economy. But this wellknown multilateral pattern of trade settlement, illustrated by S. B. Saul referring to the centrality of the U.K. (Saul 1960), also grossly underrepresents the depth of intraAsian trade, hence the importance of intra-regional trade for world trade. Intra-Asian trade is shown to have been 432 million pounds in Fig. 1.3, which corresponds to the smaller figure of 42 million in 1840 in Fig. 1.2. If the growth of intra-Asian trade at the unrecorded level was roughly at the same pace as that of the recorded one, the real amount of intra-Asian trade in 1910 must have been much larger. We will show some evidence to support this statement below. 


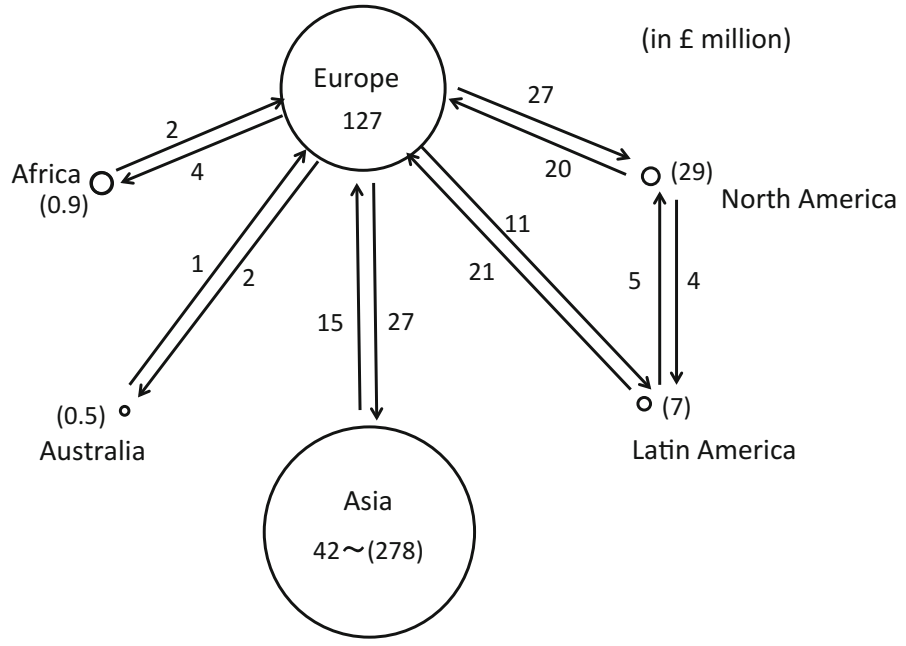

Fig. 1.2 Structure of world trade, 1840. Sources and Notes Sugihara (2015c, 29). Trade data include original estimates. Figures for each region are intra-regional trade. Those in brackets are very rough estimates. The size of the circle expresses the relative proportion of each region in world GDP (Maddison 2009)

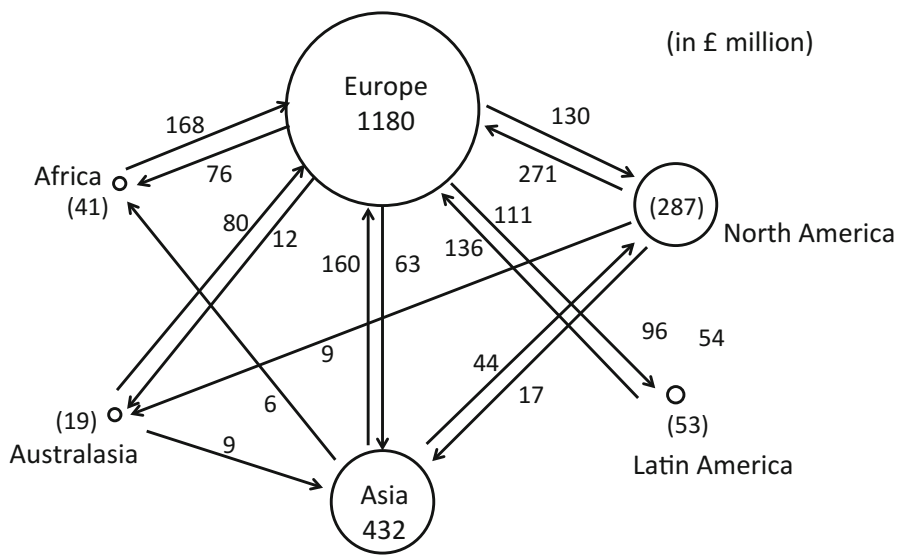

Fig. 1.3 Structure of world trade, 1910. Sources and Notes Sugihara (2015c, 33). Trade data are original estimates. Figures for each region are intra-regional trade. Those in brackets are very rough estimates. The size of the circle expresses the relative proportion of each region in world GDP (Maddison 2009) 


\subsubsection{Local and Regional Trade in British India ${ }^{2}$}

In order to show the magnitude of local and regional trade, it is useful to look at British India, a region with a massive amount of trade-related statistics. Here we show some examples of different types of statistics such as coasting trade, railand river-borne and road-borne trade, in addition to foreign trade. Figure 1.4 shows the magnitude of rail- and river-borne trade of India (largely British India except Burma, but includes many princely states) in 1888. By then large port cities such as Calcutta, Bombay and Madras (and its surrounding ports) became regional hubs of Bengal, Bombay and Madras Presidencies respectively, and rail- and river-borne, coasting and road networks were developed to link them to hinterlands, often beyond each presidency. Manufactured goods such as British cotton textiles were carried inland, and in turn primary products were brought to port cities (for details, see Sugihara 2015b). According to the traditional interpretation, this was an attempt to build a transport infrastructure through a combination of British investment in Indian railways and promotion of long-distance trade. The British government of India discouraged the development of Indian industries through tariff and exchange rate policies and preferential imports of British textile machinery and railway-related goods.

While such an account highlights an important aspect of development under colonial rule, a closer look at regional statistics indicates a more complex picture. Figure 1.5 compares foreign trade, coasting trade, rail-borne trade, river-borne trade and road-borne trade of Calcutta and its environs around 1877. According to Report on the Administration of Bengal, the source of Fig. 1.5, foreign trade amounted to 500 million rupees, while 330 million rupees of commodities were carried by rail, 40 million by steam boats, 20 million by road (captured at a small number of 'cordons'), and 190 million by 'country boats'. The traditional understanding of the role of the large port cities such as Calcutta was to import manufactured goods from abroad and distribute them to districts of Bengal and other parts of North India, and to export primary products collected from inland areas. Indeed cotton textiles, liquors and wines, and iron imported from Britain were transported by rail to other districts, while indigo, rice, linseed, wheat and raw jute were carried, mainly by rail, from Bengal, North Western Provinces and Oudh, Bihar and Punjab to Calcutta, and parts or most of them were exported. Tea was carried by steam boats from Assam to Calcutta, most of which were exported to Europe and the United States.

At the same time, those who operated in the central markets of the economy of Calcutta and its environs were mainly Indian and India-based merchants. For them Calcutta was also a place of exchange of domestic goods, with the combined use of four vastly different types of transport, railways and steam boats on the one hand, and traditional road transport and country boats on the other. From this perspective, the combined statistics reveal that the greater part of imports of rice, raw jute, linseed and grams and pulse were actually imported by country boats rather than by rail. The greater part of both salt and rice trade (imports and exports) was conducted by

\footnotetext{
${ }^{2}$ The contents of this and next section are based on Sugihara (2019b).
} 


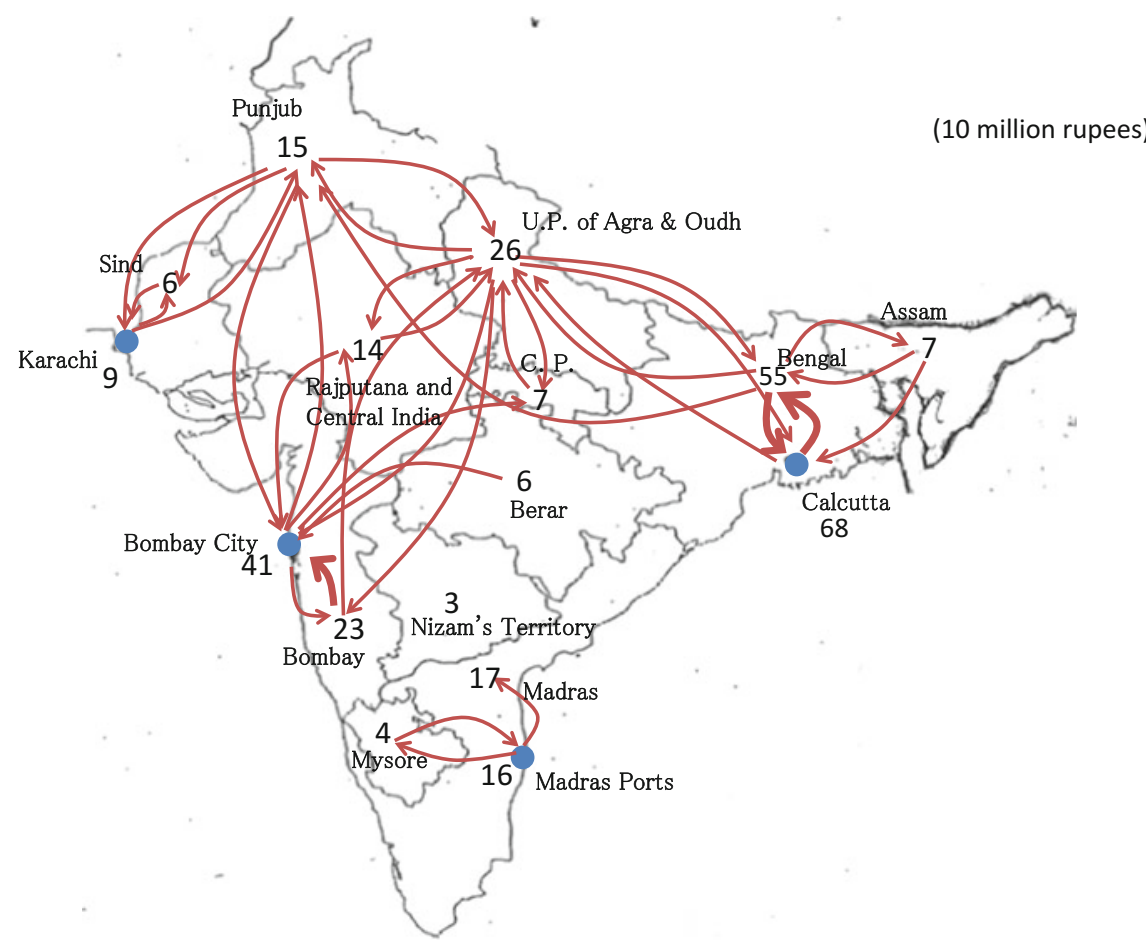

Fig. 1.4 Rail- and river-borne trade in India, 1888. Source and Notes Rail- and River-borne Trade, 1888/89-1892/93. Figures are sums of exports and imports. Thin arrows represent a million rupees and above, while thick arrow 10 million and above

country boats and road transport. In this particular year a large amount of rice and other commodities were sent to Madras under the famine. In normal years, however, a very large proportion of grains and salt that came into the city must have consumed there. Given the recording of road-borne trade was limited and a large proportion of imports to the city was consumed within, it is reasonable to assume that about a half of the commodity flows in the city economy were unrelated to foreign trade.

By the end of World War I it became the norm that the majority of rail-borne trade was more closely related to the domestic market than to foreign trade. A large part of this change came from the expansion of commodity chains driven by the growth of modern industries, such as the Bombay-driven flows of raw cotton to cotton piece goods and the Bengal-driven flows for raw jute to jute bags. At the same time, domestic markets of major grains such as rice and wheat emerged, and they were accompanied by a wide circulation of traditional spices and daily necessities. Materials for the construction and maintenance of railways, roads and urban infrastructure were also among the major items of domestic trade (Sugihara 2002, 2015b). An important feature is that railways and steam boats did not simply replace the more traditional road- and river-borne trade, but the former often activated the latter. 


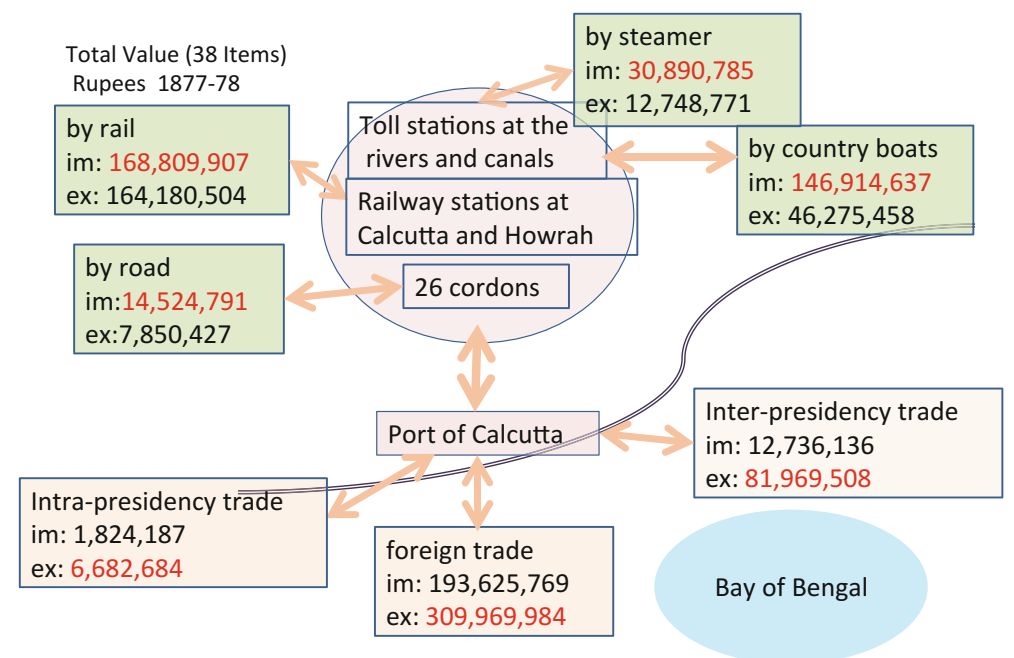

Fig. 1.5 Trade of Calcutta and its environs, 1877/78. Source Report on the Administration of Bengal (1877/78)

The growth of the domestic market was not confined to the urban centers such as Calcutta, as shown above. Construction of a railway station in the relatively remote part of inland areas, for example, often led to the construction of feeder roads from the station, and they were then often linked to traditional road networks (for Bombay presidency see Sugihara 2015b). The transport infrastructure of British India thus served, albeit in a largely unintended fashion, for the growth of the domestic market and labour-intensive industrialization.

After independence, the British-driven development of modern infrastructure was eventually transferred to serve for the domestic market, consisting of diverse local and regional merchant networks and new nation-wide networks, largely unrelated to imports and exports. Although replacement investment in railways was insufficient towards the end of the colonial period, and the independent government had to bear rather heavy costs from the beginning, the railway networks nevertheless acted as a backbone of capital-intensive industrialization. At the same time, it acted as a vehicle of the distribution of food and clothing and other necessities, which were increasingly standardized and modernized. The admittedly slow development of mass consumer culture emerged, largely as a result of activities of domestic merchants rather than with the aid of the state. 


\subsubsection{Indian Ocean Trade}

The scale of local and regional trade in India was already quite large by the time of the development of the territorial rule by the English East India Company. Even in Bengal where long-distance trade grew fast from the end of the eighteenth century, the sum of Calcutta's intra-Asian trade, trade with other parts of India, and trade within the Bengal Presidency in 1811 was still greater than Calcutta's long-distance trade. Local and regional trade was much greater than long-distance trade in Bombay and Madras for that year (Sugihara 2009).

This picture changes dramatically by 1840 . These three port cities greatly strengthened links with Britain. A large part of traditional Indian Ocean trade declined, while European manufactures penetrated into the domestic market. Even so, the distribution of European goods and the transport of primary products to port cities were largely conducted by Indian and India-based merchants. For example, sea-borne trade statistics of the city of Bombay records a large increase of both foreign trade and coasting trade. Most of raw cotton was imported to the city of Bombay from other ports of Bombay Presidency before being exported mostly to Britain (Bombay Presidency Report of the Commerce of Bombay; Bombay Trade and Navigation Annual Statements). This means that even the most typical 'long-distance trade' was not under the full control of Britain, but was dependent on the traditional trade networks. For local merchants this was a new business. Available statistics alone does not tell us a clear overall decline of local and regional networks.

Did regional trade really decline in the mid-nineteenth century onwards? It is clear that there was a strong and sustained surge of long-distance trade of British India after the 1860s, led by the sudden increase of raw cotton from Bombay in the 1860s (against the 'cotton famine') and the opening of the Suez Canal. On the other hand, a sharp decline of coasting trade only reflects the change of the recording methods of trade statistics (intra-Presidency trade statistics largely disappear from the Bombay Presidency data, for example). In reality, the establishment of the Suez Canal route led to the reorganization of both India's domestic trade and the Indian Ocean trade, involving Southeast Asia, East Asia, the Middle East, East Africa and South Africa. The rate of growth differed region by region and was not as rapid as long-distance trade, but an increase of the absolute amount of regional trade seems clear.

Figure 1.6 shows the composition of geographical distribution of trade of each country or region of the Indian Ocean and East Asia in 1910. The numbers refer to the proportion of exports to Asia and Sub-Saharan Africa to the total amount of exports. The statistics come from the presidency data of British India and the British parliamentary papers. I have included the amount of coasting trade for British India trade statistics in this calculation, on the ground that they are trades between different regional economies, and are closer to other components of intra-Asian trade (such as the trade between the Straits Settlements and Siam). The Figure however excludes all land trade (and, for that matter, all domestic trade in China), so it grossly underestimates the magnitude of local and regional trade. Nevertheless, it is clear that many major ports were oriented towards regional trade rather than long-distance 


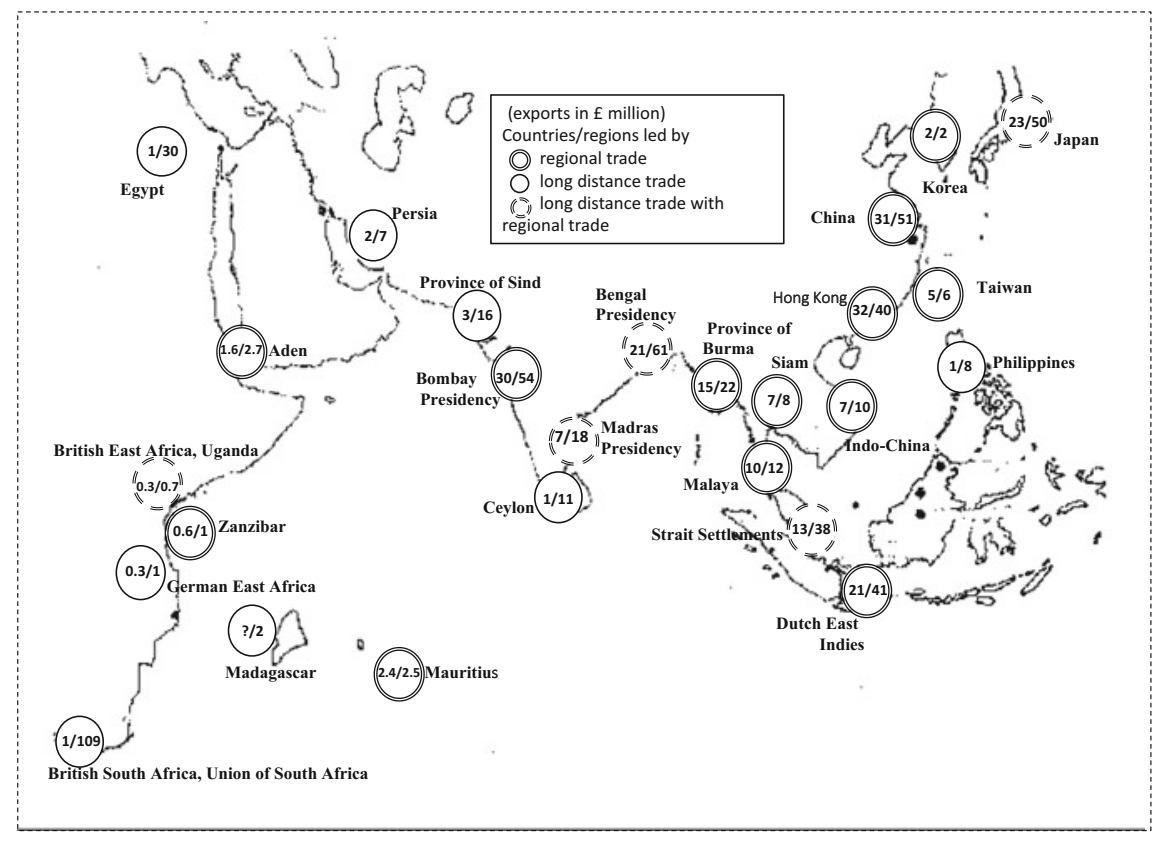

Fig. 1.6 Long distance trade and regional trade, 1910. Sources and Notes Sugihara (2013). Circles show major trading countries and regions. Figures indicated within the circle shows the value of exports to Asian and African regions over that of total exports. Figures for the Presidencies and the Provinces of India and Aden are derived from the references originally used in Sugihara (1996) (186) and Sugihara (2002) (28). Figures refer to sea-borne trade only. As coastal trade in British India is included here, the ratio of intra-regional trade is greater than the usual calculation made from the geographical composition of foreign trade. Figures for Hong Kong was estimated from those in 1913. See Sugihara (1996) (107)

trade, and that intra-Asian trade constituted an essential part of Asian trade, together with Asia's trade with the West (for other periods, see Sugihara 1996, 2005a). The regional trade was primarily conducted by merchant networks based in Asia and Africa (including some non-Asian traders based in the region).

Let us first briefly describe the nature of trade of the Indian Ocean. First, it changed from traditional commodity flows to the more 'industrialization-driven trade', that is, it increasingly included the exports of Bombay cotton cloth and other manufactured goods to other parts of Asia and imports of primary products such as rice and sugar from there for urban and rural consumption, arising from a marginal rise in the purchasing power of local population (Sugihara 1996, Chap. 6).

Second, over 30 million people migrated from India from 1834 to 1930, mainly to Ceylon, Burma and Malaya to seek employment in plantations and mines and in commercial agriculture. There was also a long-distance migration within India to work for plantations and mines. Most of these people stayed in host locations from a few months to three years, and returned home. Their income benefitted the home 
village, sometimes resulting in the improvement of the farmers' status through the purchase of cattle or land (Yanagisawa 1996). A large amount of intra-Asian trade in this period is related to such temporary migration, consisting of food and other necessities the migrants used. Indian merchant networks (and sometimes moneylenders as well) followed the migration. Indian migrants were also seen in East Africa, South Africa and the Caribbean, but an overwhelming proportion of them moved within the British Empire. Migration to regions of recent settlement (such as Canada, Australia and New Zealand) where high wages were on offer was extremely limited (Sugihara 1996, Chap. 9, 1999).

Third, activities of merchant networks based in India expanded to Southeast and East Asia. With the opening of ports to foreign trade in East Asia, Sassoons, for example, extended their networks to China and Japan, to deal with opium and other Asian produce. Given the significance of India's cotton yarn in the 1870 s to the 1890s, India clearly acted as an exporter of manufactured goods to East Asia at this stage. However, Indian merchant networks soon faced a competition from Chinese networks. Also, with the more successful industrialization of Japan, India-based merchants increasingly handled imports of Japanese manufactured goods and exports of primary products. Japan's labour-intensive industries were competitive in the relatively cheap range of cotton textiles and sundries, and penetrated into diverse consumer markets of the Indian Ocean. Japanese goods were often interpreted in local cultural contexts (for example, Japanese matches were sold in Chinese or Indian labels), and in some areas import substitution of Japanese manufactured goods took place (Sugihara 1996, Chaps. 1 and 2; Oishi 2015).

The Indian Ocean trade as an arena possessed a high level of merchant abilities of organizing trade and production. Merchant networks did not necessarily bring major innovation in production, but were capable of organizing production networks and easing local resource constraints. Thus they connected cotton producing areas to modern spinning to hand-weaving, and created commodity chains. They also created networks of grain trade, easing local food shortages and enabling peasants to specialize in commercial production. In addition to Hindu and Muslim people, Parsis, a Zoroastrian community, and Jewish merchants originally from Baghdad were among those who exploited cultural and ecological diversities in their own ways. Their presence reinforced the diverse nature of Indian Ocean trade, and helped make changes in commodity production and consumption compatible with religious and linguistic characteristics.

To put this into the longer term perspective, early modern South Asia was at the center of a large regional trading world (Chaudhuri 1985). The South Asian path of economic development was capable of coexisting with long-distance trade, a quality absent in the European path of economic development which pursued its own longdistance trade and territorial expansion, and in the East Asian path which severely restricted it. The Indian Ocean was the only large trading area that embraced regional and global commodity flows in this period. The British rulers took advantage of this quality for the economic integration of both the subcontinent and the Indian Ocean. 


\subsubsection{The Wider Contexts}

Figure 1.6 also charts East Asian countries and ports to show the relative significance of Intra-Asian trade in 1910. As indicated above, the numbers refer to the proportion of exports to Asia and Sub-Saharan Africa to the total amount of exports. At this point the bulk of trade for East Asian ports was with East Asian and Southeast Asian ports, with some crucial links with Indian ports.

We have already referred to intra-Asian cotton trade in relation to labour-intensive industrialization in Sect. 1.2. In addition, Japan imported rice and sugar from Southeast Asia before Korea and Taiwan under Japanese rule became providers of these items. By the interwar period the Chinese position shifted from an importer of cotton yarn from India and Japan to exporters of a small amount of cotton cloth to Southeast Asia, reflecting import-substitution industrialization. Perhaps more important was a large amount of remittances of overseas Chinese from Southeast Asia. Between 1891 and 1938 at least 14 million people migrated to Southeast Asia, mostly for a short period. Unlike Indian counterparts, it was relatively easy to move from labourers to merchants, and within merchant communities from small shop keepers to wholesalers to foreign traders. Dialect-based groups constituted powerful migration networks across Southern China and Southeast Asia, to freely move labourers around, often via Hong Kong and Singapore (Sugihara 2005b).

Hong Kong and Singapore also played as a hub of intra-Asian trade, linking it to both long-distance trade and intra-Southeast-Asian trade. Three chapters of this volume discuss aspects of the path dependency of Southeast Asia as a pivotal region of Asia's trade. It not only acted as a region of active trading at all levels, but played a vital role in linking economies surrounding the Indian Ocean and countries under the tributary trade system in East Asia. In early modern Asia, China and India fed the bulk of population, while first serious European contacts with East Asia were likely to be made in or through Southeast Asia. In Chap. 3 Shimada outlines Southeast Asia's long-term path of economic development, and argues for the fundamental importance of intra-Asian trade in shaping it. In Chap. 4 Ota captures the persistence and development of 'China-oriented trade' from the eighteenth to the nineteenth century, and describes the changing relationships between trade and the state. Commerce was often as important as production for state formation. At one point, part of the state functions was performed by commercial groups and their military wings. Examination of the distinct trajectory of trade-sensitive regional governance goes a long way towards explaining how it was possible for agriculturally fragile and environmentally and politically unstable parts of maritime Asia to handle an intra-regional trade of this magnitude. In Chap. 5 Kobayashi describes the growth of Singapore by examining the period from the early nineteenth to the early twentieth century, and locates it in the context of the region's path of economic development. The Western impact, colonialism and globalization did not destroy the long-term path. Development of Singapore as a trading and information hub shows that an originally colonial port city exhibited an extraordinary capacity to embrace environmental, technological and institutional diversities within the region. 
By the end of the nineteenth century Southeast Asia's imports of Indian textiles became small, and gradually shifted towards a higher value added range. By contrast exports of lower value added range of Indian cloth to East Africa remained important, and competed with European textiles to some extent. In other words, intra-regional trade sought complementarity with long-distance trade, and expanded its geographical scope by connecting to new markets on the one hand, and by upgrading the range of manufactured goods on the other.

Finally, intra-East-Asian trade grew very fast after World War I, mainly as a result of the growth of trade of Korea and Taiwan with Japan. By the late 1930s intra-yenbloc trade numerically dominated intra-Asian trade. The composition of this trade also changed to include exports of machinery, reflecting industrialization in Korea (Hori 2009). While these developments are important for the economic development of Korea and Taiwan under colonial rule, their trade was severely confined to trade with Japan. The Japanese strategy for trade expansion in Asia increasingly sought autarchy, ignoring the position of Asia in world trade. For example, the bulk of rubber exports from Malaya to the United States and Europe could not possibly have been absorbed within the imagined Japanese 'co-prosperity sphere'. Neither would Japan have survived without the imports of oil and minerals, as well as raw cotton, from outside the Japanese sphere of influence. In these respects the mechanism of pre-war intra-Asian trade was destroyed as a result of Japanese aggression. A post-war order was built on the new trend of decolonization and the Cold War divide, as well as the experiences of the war-time controlled economy.

\subsection{Paths to Industrialization}

\subsubsection{Regional Industrialization}

The previous section addressed the question of why the growth of intra-Asian trade was important for the emergence of the international division of labour, including labour-intensive industrialization. To recapture, the world economy in the long nineteenth century was not entirely generated by the dynamics of Atlantic economy, nor was it 'bipolarised' by the development of the 'enclave economies'. Looking at the period from 1820 to 1950 as a whole, the intra-regional trading sphere of Asia showed a common tendency to expand by commercializing its agriculture and reorganizing its traditional industries, and by linking modern manufacturing to this expansion, which resulted in the evolution of the system comprising the division of labour between agriculture and industry within the region. The period saw that Western powers (and regions of recent settlement) and Asia (and the tropical regions to which Asian workers emigrated) simultaneously developed high-wage and lowwage economies (see Lewis 1978: especially 194-224 for a similar formulation; for criticism see Sugihara 2013: 21, 22, 27). The former used more resources, while the latter fed more people. Uneven allocation of resources underpinned two different 
paths to industrialization. Together, they fuelled and sustained the expansion of the world economy.

During the interwar period labour-intensive industrialization was more systematically extended from Japan to China and Korea, with state and colonial reinforcement, and the 'flying geese pattern of economic development' (Akamatsu 1962) emerged between Japan and China (see Abe 2005). By 1938 intra-Asian trade, by then dominated by the Yen bloc, was the second largest area of intra-regional trade, next to intra-European trade, consisting of $9 \%$ of world trade at the level of recorded statistics.

After a heavy intervention of the emergence, development and abrupt collapse of the Yen bloc in the 1930s and the first half of the 1940s, intra-Asian trade recovered fast among a smaller number of countries. By 1950, India, China, many Southeast Asian countries, and North Korea withdrew from the regime of free trade, while the countries along the western Pacific coast (Japan, South Korea, Taiwan, Hong Kong and Malaya-Singapore among others) were integrated into the U.S.-led world economy.

Table 1.1 summarizes the growth of Asia's trade and intra-Asian trade in relation to world trade. In the early post-war period, the share of the U.S. (and other Western countries) in Asia's trade was large, and its influence was dominant. However, the U.S. share rapidly declined, and was replaced by the growth of regionally-driven trade. In 1965 the share of ten major Asian countries in world exports was 14\%, but this share increased to $23 \%$ in 2000, and to $31 \%$ in 2015. More important, the share of intra-Asian trade in Asia ten's exports increased from 35\% in 1965 to $51 \%$ in 2000 , and to $70 \%$ in 2015 , a figure comparable to intra-E.U. trade.

The post-war diffusion of industrialization, beginning in Japan and spreading to other Asian countries, followed the same interactive path between intra-regional trade and industrialization as in the prewar years, first among a small number of countries under the regime of free trade, and gradually embracing others. For example, think of the 'Asian textile complex' in the 1970s, in which Japan produced rayon yarn, Taiwan wove rayon cloth, and Hong Kong made the cloth into an apparel and exported the apparel to the United States (Arpan et al. 1984: 112-7, 136-49, 159). New intermediate goods included cheap plastics, man-made fibres, machine parts, and eventually IC chips. As in the pre-war period, we do not see such a dynamic relationship between regions in Africa, Middle East or Latin America. South Africa and Brazil proceeded with industrialization without accompanying regional integration. It is only in Asia that economic nationalism has embraced regional integration.

Generally speaking, therefore, the labour-intensive path of economic development was suited to Asia's factor endowment in relation to the rest of the world. In practice, each industrialization was country-specific (or rather the modern nation state was often created to realize industrialization and modernization). This volume offers three chapters on industrialization experiences of Japan, China and India.

The most obvious country that benefitted from both transfer of Western technology and institutions, and availability of a very large market for cheap manufactured goods in Asia was Japan. In Chap. 6 Tanimoto discusses the nature of Japan's pre-war industrialization, in which to locate labour-intensive industrialization, with special 
Table 1.1 Growth of intra-Asian trade, 1950-2014 (in billion US dollars)

\begin{tabular}{l|c|c|c|l}
\hline & (1) World exports total & (2) Asia exports total & $\begin{array}{l}\text { (3) Intra-Asian trade } \\
\text { total }\end{array}$ & $(3) /(2) \%$ \\
\hline 1950 & $58.0(100.0)$ & $10.7(18.4)$ & $2.9(5.0)$ & 27.1 \\
\hline 1955 & $93.9(100.0)$ & $13.4(14.3)$ & $4.0(4.3)$ & 29.9 \\
\hline 1960 & $128.9(100.0)$ & $18.3(14.2)$ & $5.9(4.6)$ & 32.2 \\
\hline 1965 & $188.2(100.0)$ & $25.7(13.7)$ & $9.1(4.8)$ & 35.4 \\
\hline 1970 & $320.7(100.0)$ & $44.4(13.8)$ & $15.6(4.9)$ & 35.1 \\
\hline 1975 & $887.4(100.0)$ & $143.4(16.2)$ & $49.8(5.6)$ & 34.7 \\
\hline 1980 & $2018.1(100.0)$ & $332.6(16.5)$ & $135.9(6.7)$ & 40.9 \\
\hline 1985 & $1987.0(100.0)$ & $424.2(21.3)$ & $167.7(8.4)$ & 39.5 \\
\hline 1990 & $3601.2(100.0)$ & $805.4(22.4)$ & $357.3(9.9)$ & 44.4 \\
\hline 1995 & $5325.1(100.0)$ & $1460.6(27.4)$ & $764.8(14.4)$ & 52.4 \\
\hline 2000 & $6385.6(100.0)$ & $1456.8(22.8)$ & $738.9(11.6)$ & 50.7 \\
\hline 2005 & $10369.0(100.0)$ & $2285.5(22.0)$ & $1330.0(12.8)$ & 58.2 \\
\hline 2010 & $14937.3(100.0)$ & $4495.3(30.1)$ & $3073.9(20.6)$ & 68.4 \\
\hline 2014 & $18442.9(100.0)$ & $5603.2(30.4)$ & $3905.9(21.2)$ & 69.7 \\
\hline
\end{tabular}

Sources and Notes Takanaka (2000). For figure from 2000 onwards, IMF, Direction of Trade Statistics Yearbook. The former work is based on UN commodity trade statistics, which is slightly wider in the scope of coverage than the IMF data, but the differences are small. Intra-Asian trade total refers to the value of exports from ten Asian countries (Japan, four NIEs, four ASEAN countries and China) and their imports from the smaller Asian countries (adjusted by FOB-CIF conversion)

reference to urban small-scale manufacturing industry. While the bulk of cotton textiles and sundries were indeed exported to Asia, the examples Tanimoto offers here include the growth of production of 'new' commodities, such as toys, that were mainly exported to Europe and the United States. He further links this development to the emergence of yet another generation of small-scale manufacturing in the postwar period. Tanimoto's account is an important reminder of the potential of labourintensive industries and their contributions to global industrialization.

Figure 1.7 shows that Japan adopted a policy of selective protectionism, that is, setting up tariff barriers only against imports directly competing with the domestic industry attempting import-substitution but pursuing the benefit of free trade, as a result of which her overall tariff rate stayed relatively low, while China and India raised tariff rates during the interwar period, partly for revenue purposes but also to more comprehensively protect domestic industries. Japan's dependence for the imports of raw materials was much greater than that of the other two countries.

In Chap. 7 Kubo discusses the historical processes of China's industrialization with reference to different types of states and economic policies in the twentieth century. Originally integrated into the international economy from the 1840s, mainly as exporters of tea, raw silk and other primary products, China eventually established a modern state in the 1920s and the 1930s, capable of demanding tariff autonomy 


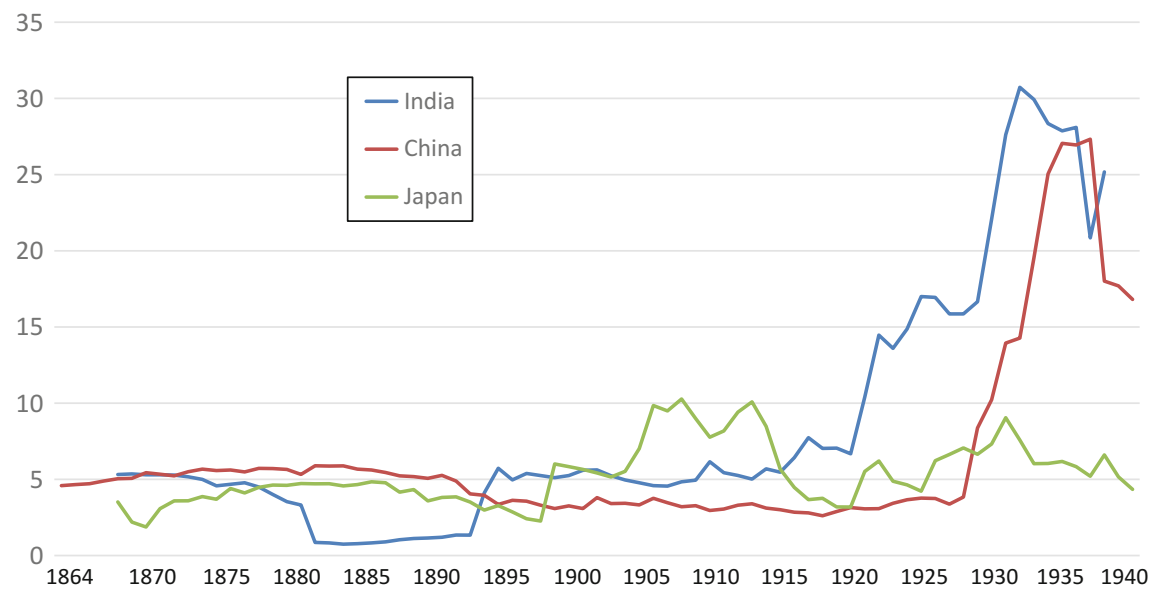

Fig. 1.7 Import tariff rates in India, China and Japan, 1864-1940. Notes and Sources India: Sugihara (2002, 30-31), China: Hsiao (1974, 22-24, 132-33), Japan: Okurasho (1948). Rates refer to the share of total import revenue divided by total value of imports. The Japanese data exclude colonial imports after 1919

and negotiating the currency reform under the Nationalist government. The selective tariff protection adopted in this period can be interpreted as an import-substitution industrialization strategy under the regime of free trade (Kubo 2005). However, Kubo then turns to the various regimes emerging under the war-time conditions, in which he skillfully describes the economic policies of Manchuria, the Nationalist government, the communist regime etc., and their changing relationships. He emphasizes that elements of 'planned economy' were variously experimented in this period, which formed the basis for the economic policy of communist China during the Mao period. For Kubo, industrialization of China was best characterized as a parallel development of capital-intensive and labour-intensive industries. The nature of the state in the planning economy period is distinct in the sense that it aimed at the strengthening of political and economic power of the country rather than following the signals of comparative advantage of each industry in international market place. Even so, after the policy reform China was able to take advantage of its comparative advantage to export labour-intensive products in massive quantities. There are similarities and a degree of continuities between the pre-war path and post-reform path (see Pomeranz 2013).

Although the first modern cotton industry in Asia took root in Bombay in the 1850s, labour-intensive industrialization was less successful in colonial India than in Japan and perhaps China. In Chap. 8 Nomura compares factor endowments of labour and capital between India and Japan, to show that labour abundant and capital scarce conditions, which prompted Japan to proceed with labour-intensive industrialization, were not present in India as clearly as in Japan. The laissez-faire economic policy, including free trade, is not in themselves a sufficient condition for stagnant 
industrialization, although it may have affected the potentiality of industrialization through the fiscal stringency of the British government of India, leading to the lack of encouragement of education, for example. It also argues that other factors such as the slow technological transfer arising from the nature of Indian organization and management must be taken into account.

In independent India, import-substitution industrialization strategy made it difficult to pursue labour-intensive industrialization, in spite of the fact that it had long historical roots (Roy 2005, Chap. 6). There was the heritage of the nationalist movement, which advocated the protection and development of traditional cottage industries, including economically inefficient sectors like khadi and handloom segments. Partly inheriting the Gandhian tradition and partly in a more explicit effort to create employment, these sectors had been isolated from international competition. Meanwhile, the government protected the large-scale modern cotton textile industry, which in turn provided the traditional weaving industries with cheap machine-made yarn. Labour in the organized sector was legally protected, which made it difficult for any factory to lay off its workers. Furthermore, because of the virtual prohibition of the imports of textile machinery and the installation of new machinery in the factory, there was little chance of raising productivity or improving the quality of yarn. As a result, the Indian cotton textile industry went through a long period of isolation from the rapid technological advance in Asian countries, led by Japan. More generally, the ideology for the political and economic autonomy remained powerful in India.

In India several attempts were made to liberalize the economy after 1965 without much success. The policy shift of 1991 realized a degree of liberalization of trade and capital flows, and was a step towards deregulation, but it did not represent a major ideological change in economic policy among the Indian elites. In particular, the rate of increase in the expenditure on education and welfare for the ordinary people, relative to that for elites, has been slow. Yet a high level of capability based on primary and secondary education (the literacy rate remains a major problem) and hygiene (especially low infant mortality) is clearly a necessary, though not sufficient, condition for economic development. In this respect the Chinese achievement during the pre-reform period (1949-1979) was far more impressive (Dreze and Sen 1995, 1997).

Nevertheless, the economic reforms of 1991 sharply corrected India's bias towards strong economic ties with the Soviet Union and other socialist countries. Export growth in the 1990s mainly came from labour-intensive industrial goods, including woven cloth, knitwear, garments, leather, machine components and software. Primarily through exports of textiles and apparel, India became progressively integrated into the international economy during the 1990s (Sugihara 2001). By 2000 India was trading more with the Asia-Pacific countries than with Western Europe, the Middle East, the former socialist countries and Africa combined. 


\subsubsection{The Resource Nexus}

From the perspective of spatial resource allocation, particularly important was the expansion of the scope of competitive modern industries in Japan: Prewar industrialization was largely based on light industries (for textiles and sundries) and was labour-intensive, while the post-war path included heavy and chemical industries (for steel, machinery and petrochemical products), which were usually more capitaland resource-intensive. Imports of fossil fuels, including oil, and raw materials from all over the world became essential to the economic growth of Asia. Thus, during the period of high-speed growth, geography, human habitat and resource use were redefined and relocated to accommodate them. A number of industrial complex were created, typically along the Pacific coast, with transport connections to major urban centers. The spatial allocation of human and natural resources was now driven by the need to secure access to industrial imports, as well as by the availability of land, capital and labour. A large proportion of population moved to cities, or a large part of rural areas became administratively 'urban', to develop the mass domestic consumer market. In prewar Japan rural industrialization remained important, especially in labour-intensive industries, while agriculture provided industry with labour force, purchasing power and food and raw materials. Traditional considerations for industrial locations included local employment with relatively low wages (e.g. female by employment in the peasant household economy), and supply of water, food and energy (both biomass and electricity). All of these functions had to be retained under the industrial-complex-driven national land development policy, and the value of natural resources (e.g. land, forest, water) reassessed under the new light, not least because sections of new industries needed to use lots of water, while others needed clean air. In fact most heavy and chemical industries, which depended on the imports of raw materials and energy for their production, simultaneously needed some non-tradable resources (e.g. land and water), competing for their procurement with traditional users.

Urbanization also changed the traditional resource endowment regime, which dominated the pre-fossil-fuel economy. This first happened in Japan (In 1945 the rate of urbanization in Japan and other parts of Asia was significantly lower than in industrial countries in the West. See Sugihara 2003, 111-2). Urban space not only combined basic livelihood needs such as water, food and electricity with employment in manufacturing, distribution and services, but added new demands such as education, health and leisure, as well as the urban transportation system. The 'civil' living space, that is, free from air pollution and congestion, became a target for local government and citizens movement. Capital- and resource-intensive industries began to be pushed out from urban and suburban landscapes, and were increasingly relocated to rural areas (Kobori 2017). Tokyo grew into the first mega-city, while Osaka and other major cities followed. The rate of growth of cities was very rapid. The critical aspects of this development lay in the perceived combination of industrial development and the securement of civil and environmentally acceptable living space through the negotiation between national land development plans, local government 
initiatives and the citizens movement. The general direction of the political process was to enable heavy and chemical industrialization to take root, without entirely losing rural landscapes and civil living spaces in urban settings.

Overall, however, the driving force behind the reorganization of economy and ecology was 'developmentalism' behind the central government policy. The concurrent growth of cities and the industrial complex created an 'urban-industrial nexus' where various tradable and non-tradable resources were identified as a set of 'factor endowments' necessary for creating an international 'comparative advantage' of manufacturing industry. Labour-intensive manufacturing in urban areas was embedded in the newly created 'resource nexus', with intensive use of space, and retained its strength, along with capital- and resource-intensive industries in the industrial complex (see Sugihara 2019a).

\subsubsection{Structural Transformation in Southeast Asia}

Southeast Asia as a region experienced perhaps the fastest structural transformation in global history from the export economies of primary products to industrialized countries. In 1950 four countries of Southeast Asia (Indonesia, Philippines, Malaysia and Thailand; hereafter ASEAN 4) and Singapore (territorial changes were adjusted wherever possible) were all exporters of primary products par excellence. By the end of the twentieth century they became exporters of labour-intensive manufactured goods and importers of capital-intensive manufactured goods. Following the lead of South Korea and Taiwan, a rapid shift took place in the 1970s and the 1980s. Figures 1.8 and 1.9 suggest a fundamental change in the five countries' position in the international economy.

There are at least three reasons why Southeast Asia managed to transform itself so quickly. First, the region successively found the market for their products in the postwar period, first by exporting primary products to the expanding American market, then by participating in the commodity chain of labour-intensive manufactured goods initiated by Japanese, American and other foreign companies, and finally exporting competitive labour-intensive manufactured goods by themselves or in corporation with multinational companies. After the second half of the 1960s, it was able to benefit from foreign investment and, through it, the transfer of technological and managerial knowledge for industrial development. Although the region suffered many wars and conflicts, and many other Southeast Asian countries were left out from this dynamics for a long time, ASEAN slowly expanded its membership and steadily increased its economic influences.

Second, against the background of population growth, there was a growth of labour-intensive industries, which absorbed labour. In 1974 Indonesia, for example, had manufacturing employment of around four million, mostly in very small establishments in rural areas engaging in food processing and other traditional industries (van der Eng 2013). This was too big a sector for the capital-intensive manufacturing sector to absorb. In 1970 Harry Oshima argued for a systematic effort to make these 
1 Multiple Paths to Industrialization: A Global Context ...

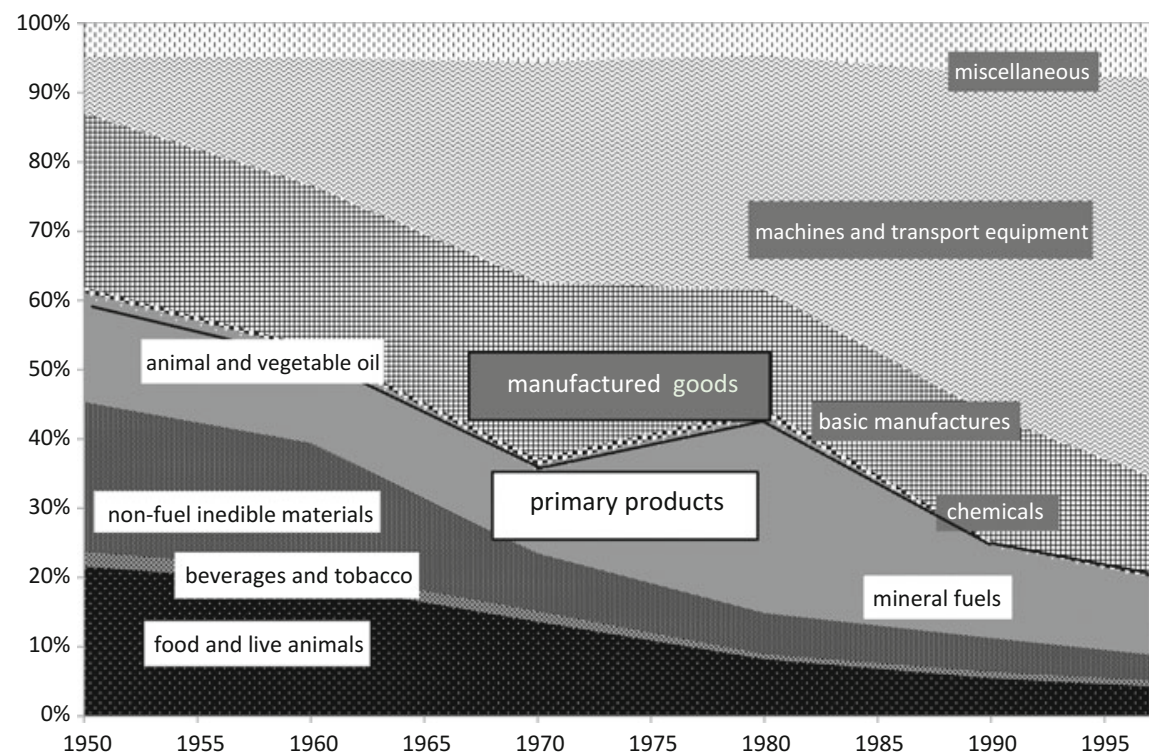

Fig. 1.8 Commodity composition of exports from 4 ASEAN countries and Singapore, 1950-1997. Source Takanaka (2000)

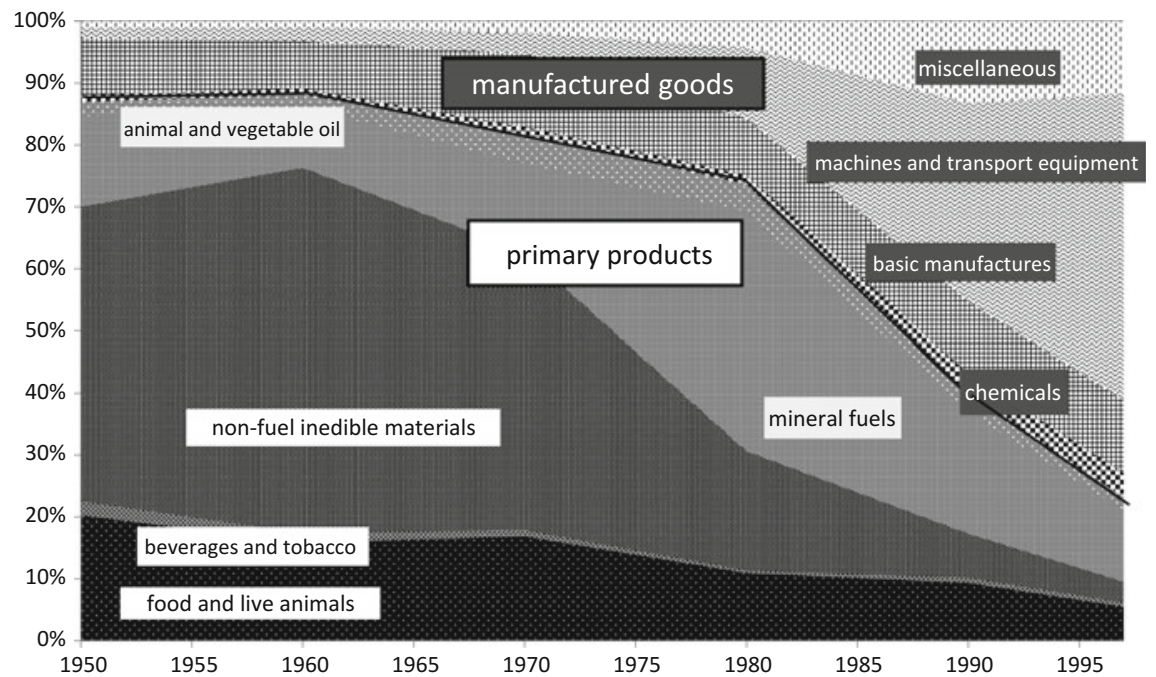

Fig. 1.9 Commodity composition of imports to 4 ASEAN countries and Singapore, 1950-1997. Source As per Fig. 1.8 
small industries internationally competitive, with a fuller and the more efficient use of labour, training of skilled labour, better marketing and the more detailed government support for information gathering and export promotion (Oshima 1970). This was a strategy close to the East Asian (especially Japanese) path, signalling a clear departure from the heavy industry orientation the earlier orthodoxy had advocated. On the one hand, labour, both rural and urban, was absorbed into sweat shops and modern factories as unskilled labour, with low wages and harsh working conditions. The society became unequal in many ways. At the same time, ethnic and institutional barriers to social mobility became less serious, and increasingly large numbers of primary and secondary school graduates with better health became available. And the quality of workforce gradually improved. This was a major reason why the pace of industrialization of ASEAN 4 accelerated by the 1980s, overtaking early industrializers such as India.

Third, it was on this basis that export-oriented industrialization strategy diffused rapidly. In many respects the strategy looked 'shallow'; It was externally induced (often with export processing zones and other government measures to promote investment of multinational companies); The sequential upgrading of an industrial structure, typically seen in earlier industrializations from light industry to heavy industry with all 'basic' industries and complicated linkages, was missing; The land reform was incomplete, and rural inequality remained a macroeconomic issue. But it was not a shallow kind of industrialization, in the sense that it was supported by competitive labour (cheap labour able to produce goods in a competitive market). It was natural that countries of NIEs and ASEAN 4 with smaller population were keener on export-orientation than the United States or Japan (both with a low ratio of trade to GDP). The growth of a relatively homogenous market for cheap, labourintensive manufactured goods across East and Southeast Asia, as well as the lower end of the American market, made a regional industrialization possible.

The core ideology behind this process was 'developmentalism' which was created to pool all the resources for economic development (Suehiro 1998). It advocated both regional and international economic cooperation through trade, capital flows and technological transfer in strongest terms. Part of this idea came from Japan and diffused to NIEs to ASEAN countries, and, helped by Australians, took the form of 'open nationalism' (Garnout and Drysdale 1994). It argued for a free trade within the region, but without discriminating against outsiders. Southeast Asia played a key role in the diffusion of this principle. And its economic success, linking intra-Asian dynamism to world trade, was eventually to help China and India to change course. Developmentalism was distinct from both the principle of unfettered free trade without national and regional considerations, and socialism with emphasis on planning and autonomy. Although its practice suffered from authoritarian rule and the Cold War divide, it was committed to raising living standards for the ordinary people, and survived the criticisms of liberal democracy and 'market fundamentalism'. Developmentalism was not only the guiding principle of the developmental state. It largely created a regional order. 


\subsection{Paths to the Emerging State}

\subsubsection{A Summary}

The notions of multiple development paths and the emerging state in the periphery do not come directly from the Eurocentric perspective of the diffusion of industrialization or civilizing missions of imperialism. The terms adopted here do not assume a country-based linear stage theory, in which a nation such as England and Japan would make a transition from feudalism to capitalism or from pre-industrial to an industrial nation. In Asia and Africa the development path of each country was often non-linear, with plenty of disturbances from colonialism, famines and epidemics and environmental degradations, and its pace was largely determined by their own socio-cultural preferences (or reservations) for economic development. While all countries have been affected by the forces of global industrialization and economic development in one way or another, we note that the path each country followed was diverse, non-linear and more locally and regionally rooted than standard economic history and development economics had allowed for.

This chapter mainly discussed the trade and industrialization components of this view, largely leaving the issues relating to agriculture to Chap. 2. Its aim was to identify relevant historical contexts, that is, the 'initial conditions' and internal and external forces which governed the path, and to understand what current developing countries with low-income economies require for their transition to the emerging state. We suggested that local and regional trade fed employment in agriculture and industry, hence population-carrying capacity, by mitigating local resource constraints. Given the nature of constraints, long-distance trade is not always a solution. We end our discussion with a brief observation on Sub-Saharan Africa, to suggest that the emerging state should implement a development plan to promote local and intra-regional trade, to more systematically link resource exports to an increase of agricultural and industrial production and employment.

\subsubsection{Intra-regional Trade of Sub-Saharan Africa}

Historically, Sub-Saharan Africa actively engaged with local, regional and long distance (intercontinental) trade. After the decline of slave trade and the rise of 'legitimate commerce' in the nineteenth century, the region began to export primary products to Europe and other places. With the integration of local and regional economies into world trade, the former responded to the trade opportunities created within the region.

However, at the level recorded as foreign trade statistics, intra-regional trade declined sharply after the First World War, never to be recovered till the end of the twentieth century. 
Table 1.2 shows the growth of trade and the proportion of intra-regional trade in Sub-Saharan Africa for a period similar to Table 1.1..$^{3}$ The proportion of Sub-Saharan Africa in world trade has always been small, and most of exports went outside the region, especially to advanced industrial countries. Europe remained the major trading partner throughout the second half of the twentieth century. More important, Sub-Saharan Africa as a whole has always acted as a primary producer exchanging the regional natural resources for manufactured goods and services, in spite of industrialization of some countries such as South Africa. Main export commodities changed over time, but the tendency for each country to rely on a single commodity such as oil persisted. The export diversification index has not improved much. Each economy remained a satellite linked to the metropolis.

A closer look at the Table suggests that the proportion of intra-regional trade began with $11 \%$ in 1950 , and then went down because Rhodesia's trade statistics became unavailable (trade actually collapsed too), but the statistical collection was restored since around 1965, and the coverage of countries were more or less stabilized since. The Table clearly shows a surge of the amount of intra-regional trade, but the more important comparative observation is that the level of intra-regional trade had

Table 1.2 The growth of intra-regional trade in Sub-Saharan Africa, 1950-2015 (in billion US dollars)

\begin{tabular}{l|l|l|l|l|l}
\hline & $\begin{array}{l}\text { (1) World trade } \\
\text { total }\end{array}$ & $\begin{array}{l}\text { Number } \\
\text { of } \\
\text { countries }\end{array}$ & $\begin{array}{l}\text { (2) Sub-Saharan } \\
\text { Africa's (SSA) } \\
\text { exports to the } \\
\text { world }\end{array}$ & $\begin{array}{l}\text { (3) SSA exports to } \\
\text { SSA }\end{array}$ & (3)/(2) \\
\hline 1950 & $47.63(100.00)$ & 13 & $2.16(4.53)$ & $0.24(0.50)$ & 11.12 \\
\hline 1955 & $82.41(100.00)$ & 13 & $2.69(3.27)$ & $0.10(0.12)$ & 3.75 \\
\hline 1960 & $105.98(100.00)$ & 24 & $3.14(2.97)$ & $0.12(0.11)$ & 3.75 \\
\hline 1965 & $159.92(100.00)$ & 36 & $6.86(4.29)$ & $0.64(0.40)$ & 9.38 \\
\hline 1970 & $281.56(100.00)$ & 43 & $10.24(3.64)$ & $0.97(0.34)$ & 9.44 \\
\hline 1975 & $771.15(100.00)$ & 42 & $26.15(3.39)$ & $1.56(0.20)$ & 5.98 \\
\hline 1980 & $1,830.87(100.00)$ & 43 & $43.73(2.39)$ & $2.83(0.15)$ & 6.47 \\
\hline 1985 & $1,872.67(100.00)$ & 44 & $47.94(2.56)$ & $2.60(0.14)$ & 5.42 \\
\hline 1990 & $3,375.34(100.00)$ & 44 & $61.68(1.83)$ & $4.82(0.14)$ & 7.82 \\
\hline 1995 & $5,070.79(100.00)$ & 44 & $68.56(1.35)$ & $8.11(0.16)$ & 11.83 \\
\hline 2000 & $6,412.83(100.00)$ & 45 & $92.09(1.44)$ & $12.07(0.19)$ & 13.10 \\
\hline 2005 & $10,398.42(100.00)$ & 45 & $184.15(1.77)$ & $23.68(0.23)$ & 12.86 \\
\hline 2010 & $15,133.15(100.00)$ & 45 & $331.45(2.19)$ & $60.19(0.40)$ & 18.16 \\
\hline 2015 & $16,386.42(100.00)$ & 46 & $295.29(1.80)$ & $63.60(0.39)$ & 21.54 \\
\hline$S 0 u r e$ & & 49 & & & \\
\hline
\end{tabular}

Source IMF, IMF Data, Access to Macroeconomic and Financial Data, Direction of Trade Statistics http://data.imf.org/?sk=9D6028D4-F14A-464C-A2F2-59B2CD424B85\&sId=1409151240976

\footnotetext{
${ }^{3}$ The sources of the two tables, both originally from IMF, slightly differ, and so does the amount of world trade, but they do not affect main observations here.
} 
remained low. The crucial issue is not so much import-substitution of a single country as its lack on a regional scale.

Figures 1.10 and 1.11 show the geographical distribution of Sub-Saharan Africa's exports and imports respectively from 1990 to 2017. Between 2000 and 2105 the main trading partners changed from Europe and the United State to emerging and developing countries, including China and India. But there was little change in the components of exports, which were concentrated on a few commodities, especially oil and mineral resources, without much processing before exports. Imports, on the other hand, consisted of goods for infrastructure building and consumer goods. There was little progress on the exports of labour-intensive manufactured goods and processed food-stuffs from the region.

In fact, African Economic Outlook argues, there is a huge potential for the development of labour-intensive manufacturing exports within the region. 'Trade between African countries has the greatest potential for building sustainable economic development' (AfDB/OECD/UNDP 2017, 82). At the moment, however, most of the labour-intensive manufactured goods and processed food-stuffs which could be provided within the region are imported from emerging economies, especially from China and other Asian countries. In fact, amongst the surge of the proportion of intra-African trade in total African exports between 2005 and 2015, the proportion of intra-African trade in manufactured goods in total African manufacturing exports declined from 18 to $15 \%$ (ibid, 83-84. Figures refer to Africa rather than Sub-Saharan Africa). 'Transportation and communication infrastructure for intra-African trade is less developed than those that connect Africa to the rest of the world. This under-

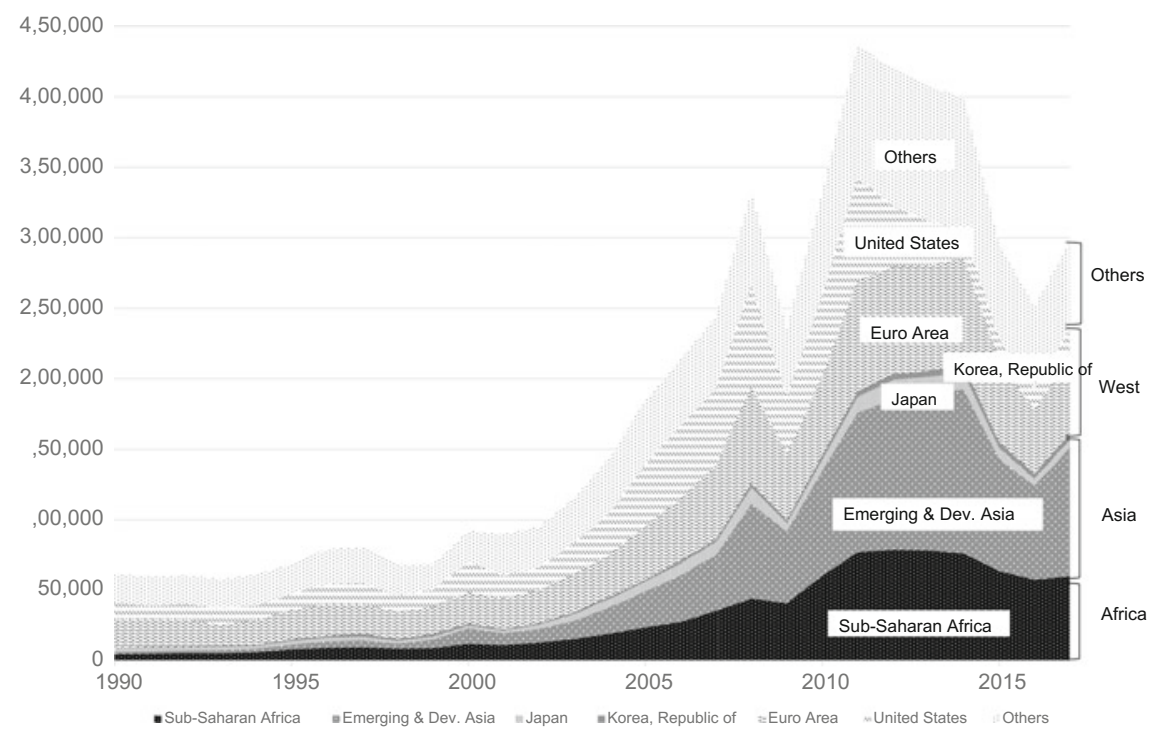

Fig. 1.10 Geographical composition of exports from Sub-Saharan Africa, 1990-2017. Source As per Table 1.2 


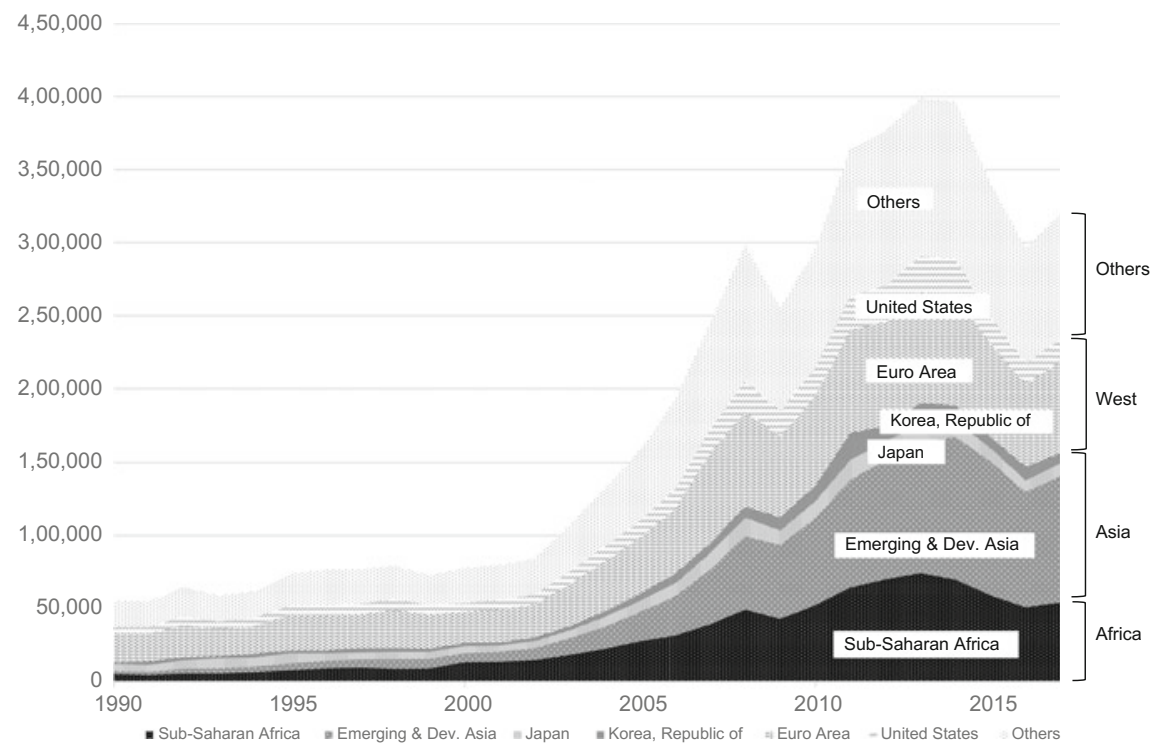

Fig. 1.11 Geographical composition of imports from Sub-Saharan Africa, 1990-2017. Source As per Table 1.2

mines the impacts of regional integration and development' (ibid. 89). In any case, 'Africa's imports of heavy machinery and transport equipment are among the lowest in the world' (ibid. 80). 'Light manufacturing could help Africa reduce its imports from outside the continent and increase intra-African trade with countries that have agricultural production and processing capacity' (ibid, 78).

Chapter 9 endorses the view that much of Africa's growth of GDP and employment in the recent period came from the service sector and improved agricultural productivity (reflecting the declining share of agricultural employment), and argues the need for the development of the labour-intensive sector and industrial policy to effect it. Perhaps we should go back to the pre-war intra-Asian trade to find a parallel situation in Southeast Asia, where a combination of merchant networks, trading and information hubs and trade-sensitive regional governance offered critical 'initial conditions' for structural transformation.

\section{References}

Abe, T. (2005). The Chinese market for Japanese cotton textile goods, 1914-30. In K. Sugihara (Ed.), Japan, China and the growth of the Asian International Economy, 1850-1949 (pp. 49-100). Oxford: Oxford University Press.

AfDB/OECD/UNDP. (2017). Trade policies and regional integration in Africa. In African Economic Outlook 2017: Entrepreneurship and Industrialisation. Paris: OECD Publishing. 
Akamatsu, K. (1962). A historical pattern of economic growth in developing countries. Developing Economies, Preliminary Issue, 3-25.

Allen, R. C. (2005). Farm to factory: A reinterpretation of the Soviet Industrial Revolution. Princeton: Princeton University Press.

Arpan, J. S., Barry, M., \& Van Tho, T. (1984). The textile complex in the Asia-Pacific region: The patterns and textures of competition and the shape of things to come. Research in International Business and Finance, 4-B, 101-164.

Austin, G. (2013). Labour-intensive industrialization and global economic development: Reflections. In G. Austin \& K. Sugihara (Eds.), Labour-intensive industrialization in global history (pp. 280-302). London: Routledge.

Bagchi, A. K. (1976). Deindustrialization in India in the nineteenth century: Some theoretical implications. Journal of Development Studies, 12(2), 135-164.

Bairoch, P. (1982). International industrialization levels from 1750 to 1980. Journal of Economic History, 11(2), 269-333.

Bombay Presidency Report of the Commerce of Bombay, Bombay.

Bombay Trade and Navigation Annual Statements, Bombay.

Chaudhuri, K. N. (1985). Trade and civilisation in the Indian Ocean: An economic history from the rise of Islam to 1750. Cambridge: Cambridge University Press.

Dreze, J., \& Sen, A. (1995). India: Economic development and social opportunity. Delhi: Oxford University Press.

Dreze, J., \& Sen, A. (1997). Indian development: Selected regional perspectives. Delhi: Oxford University Press.

Engerman, S. L., \& Sokoloff, K. L. (2011). Economic development in the Americas since 1500: Endowments and institutions. Cambridge: Cambridge University Press.

Garnout, R., \& Drysdale, P. (1994). Asia Pacific regionalism: The issues. In R. Garnout \& P. Drysdale (Eds.), Asia Pacific regionalism: Readings in international economic relations (pp. 1-7). Pymble, Australia: Harper Educational.

Gerschenkron, A. (1962). Economic backwardness in historical perspective: A book of essays. Cambridge, MA: Belknap Press of Harvard University Press.

Hori, K. (2009). Higashi-Ajia Shihonshugishi-ron 1 (Treatise on the history of East Asian Capitalism, Part 1). Kyoto: Mienruva Shobo.

Hsiao, L. (1974). China's foreign trade statistics, 1864-1949. Cambridge, MA: Harvard University Press.

India Annual Rail- and River-borne Trade Returns, 1888/89-1892/93, Calcutta.

International Monetary Fund (IMF) (various years), Direction of Trade Statistics Yearbook.

International Monetary Fund (IMF), Direction of Trade Statistics. http://data.imf.org/?sk= 9D6028D4-F14A-464C-A2F2-59B2CD424B85\&sId=1409151240976. Accessed August 24, 2018.

Jones, E. L. (1981). The European miracle: Environments, economies and geopolitics in the history of Europe and Asia. Cambridge: Cambridge University Press.

Kobori, S. (2017). Rinkai kaihatsu, kogai taisaku, shizen hogo: Kodo seicho-ki Yokohama no kankyoshi (Seafront development, anti-pollution policy and nature conservation: An environmental history of Yokohama in the period of high-speed growth). In S. Shoji (Ed.), Sengo Nihon no Kaihatsu to Minshushugi: Chiiki ni Miru Sokoku (Development and democracy of Japan in the post war era: The conflicts seen from the region) (pp. 71-104). Kyoto: Showado.

Kubo, T. (2005). The tariff policy of the nationalist government, 1926-36: A historical assessment. In K. Sugihara (Ed.), Japan, China and the growth of the Asian International Economy, 1850-1949 (pp. 145-176). Oxford: Oxford University Press.

Lewis, W. A. (1954). The economic development with unlimited supplies of labour. Manchester School of Economic and Social Studies, 22(2), 139-191.

Lewis, W. A. (Ed.). (1970). Tropical development, 1880-1913: Studies in economic progress. Evanston: Northwestern University Press.

Lewis, W. A. (1978). Growth and fluctuations, 1870-1913. London: George Allen and Unwin. 
Maddison, A. (2009). Statistics on world population, GDP and per capita GDP, 1-2008 AD. http:// www.ggdc.net/maddison/.

Oishi, T. (2015). Kan-indoyo sekai to indojin shonin, kigyoka no nettowaku: Shokuminchi-ki ni okeru fukugosei, tayosei (The world of Indian Ocean Rim and Indian merchant-entrepreneur networks: Plurality and diversity in the colonial period). In A. Tanabe, K. Sugihara, \& K. Wakimura (Eds.), Shirizu Gendai Indo 1: Tayosei Shakai no Chosen (Challenges for a diversity-driven society: Contemporary India Series 1) (pp. 169-196). Tokyo: Tokyo Daigaku Shuppankai.

Okurasho Shuzeikyoku [Japanese Ministry of Finance Government Bureau of Taxation]. (1948). Dai-15-kai Kokkai Kanzei Sankosho (Reference material on customs tariff for the 15th Parliament). Tokyo: Okurasho.

Oshima, H. (1970). The role of small industries in the acceleration of Asian growth. In Economic Commission for Asia and the Far East (ECAFE), Small industry bulletin for Asia and the Far East (Vol. 7, pp. 134-136). New York: U. N.

Oshima, H. (1987). Economic development in Monsoon Asia: A comparative study. Tokyo: University of Tokyo Press.

Pomeranz, K. (2000). The great divergence: China, Europe, and the making of the modern world economy. Princeton: Princeton University Press.

Pomeranz, K. (2013). Labour-intensive industrialization in the rural Yangzi Delta: Late imperial patterns and their modern fates. In G. Austin \& K. Sugihara (Eds.), Labour-intensive industrialization in global history (pp. 122-143). London: Routledge.

Report on the Administration of Bengal, 1877/78, Calcutta.

Richards, J. (2003). The unending frontier: An environmental history of the early modern world. Berkeley: University of California Press.

Roy, T. (2005). Rethinking economic change in India: Labour and livelihood. London: Routledge.

Saul, S. B. (1960). Studies in British overseas trade, 1870-1914. Liverpool: Liverpool University Press.

Suehiro, K. (1998). Hatten tojokoku no kaihatsu-shugi (Developmentalism in developing countries). In Tokyo Daigaku Shakai Kagaku Kenkyusho (Ed.), 20-seiki Sekai Shisutemu 4: Kaihatsu-shugi (The World System of the twentieth century 4: Developmentalism) (pp. 13-46). Tokyo: Tokyo Daigaku Shuppankai.

Sugihara, K. (1996). Ajia-kan Boeki no Keisei to Kozo (Patterns and development of intra-Asian trade). Kyoto: Mineruva Shobo.

Sugihara, K. (1999). Kindai sekai shisutemu to ningen no ido (The modern world system and human migration). In Iwanami Koza Sekai Rekishi 19: Chiiki o Musubu Dainamizumu (Iwanami lectures of the World History 19: Dynamic forces that connect regions) (pp. 3-64). Tokyo: Iwanamai Shoten.

Sugihara, K. (2001). India and the rise of the Asia-Pacific economy, c. 1947-1997. In N. Kondo (Ed.), The 'Nation-State' and Transnational Forces in South Asia. Research project 'Institutions, Networks and Forces of Change in Contemporary South Asia' (pp. 43-67), Tokyo, March 2001, Conference Proceedings.

Sugihara, K. (2002). Indo kindaishi ni okeru enkakuchi boeki to chiiki koeki, 1868-1938-nen (The long-distance trade and regional trade in modern Indian history, 1868-1938). Toyo Bunka, 82, $1-46$.

Sugihara, K. (2003). The East Asian path of economic development: A long-term perspective. In G. Arrighi, T. Hamashita, \& M. Selden (Eds.), The resurgence of East Asia: 500, 150 and 50 year perspectives (pp. 78-123). London: Routledge.

Sugihara, K. (2005a). An introduction. In K. Sugihara (Ed.), Japan, China and the growth of the Asian International Economy, 1850-1949 (pp. 1-19). Oxford: Oxford University Press.

Sugihara, K. (2005b). Patterns of Chinese emigration to Southeast Asia, 1869-1939. In K. Sugihara (Ed.), Japan, China and the growth of the Asian International Economy, 1850-1949 (pp. 244-274). Oxford: Oxford University Press.

Sugihara, K. (2009). The resurgence of intra-Asian trade, 1800-1850. In G. Riello \& T. Roy (Eds.), How India clothed the world: The world of South Asian textiles (pp. 1500-1850). Leiden: Brill. 
Sugihara, K. (2013). Labour-intensive industrialization in global history: An interpretation of East Asian experiences. In G. Austin \& K. Sugihara (Eds.), Labour-intensive industrialization in global history (pp. 20-64). London: Routledge.

Sugihara, K. (2015a). Global industrialization: A multipolar perspective. In J. R. McNeill \& K. Pomeranz (Eds.), Cambridge world history. Volume 8: Production, connection and destruction, 1750-Present (1, pp. 106-35). Cambridge: Cambridge University Press.

Sugihara, K. (2015b). Shokuminchiki ni okeru kokunai shijo no keisei (Formation of a domestic market in the colonial period). In A. Tanabe, K. Sugihara \& K. Wakimura (Eds.), Shirizu Gendai Indo 1: Tayosei Shakai no Chosen (Challenges for a diversity-driven society: Contemporary India Series 1) (pp. 197-221). Tokyo: Tokyo Daigaku Shuppankai.

Sugihara, K. (2015c). Asia in the growth of world trade: A re-interpretation of the 'long nineteenth century'. In U. Bosma \& A. Webster (Eds.), Commodities, ports and Asian maritime trade $c$. 1750-1950 (pp. 17-58). Basingstoke: Palgrave Macmillan.

Sugihara, K. (2017). Monsoon Asia, intra-regional trade and fossil-fuel-driven industrialization. In G. Austin (Ed.), Economic development and environmental history in the anthropocene: Perspectives on Asia and Africa (pp. 119-144). London: Bloomsbury Academic.

Sugihara. K. (2019a). Varieties of industrialization: An Asian regional perspective. In G. Riello \& T. Roy (Eds.), Global economic history (pp. 195-214). London: Bloomsbury Academic.

Sugihara, K. (2019b). Guro-baru hisutori no nakano minami ajia (South Asia in global history). In N. Nagasaki (Ed.), Taikei Minami Ajia-shi 4: Kingendai (Outline of South Asian history 4: The modern and contemporary period). Tokyo: Yamakawa Shuppansha.

Takanaka, K. (2000). Higashi-ajia Choki Keizai Tokei 9: Gaikoku Boeki to Keizai Hatten (Longterm economic statistics of East Asia. Volume 9: Foreign trade and economic development). Tokyo: Keiso Shobo.

van der Eng, P. (2013). Government promotion of labour-intensive industrialization in Indonesia, 1930-1975. In G. Austin \& K. Sugihara (Eds.), Labour-intensive industrialization in global history (pp. 176-200). London: Routledge.

Yanagisawa, H. (1996). A century of change: Caste and irrigated lands in Tamilnadu, 1860s-1970s. New Delhi: Manohar.

Open Access This chapter is licensed under the terms of the Creative Commons AttributionNonCommercial-NoDerivatives 4.0 International License (http://creativecommons.org/licenses/bync-nd/4.0/), which permits any noncommercial use, sharing, distribution and reproduction in any medium or format, as long as you give appropriate credit to the original author(s) and the source, provide a link to the Creative Commons licence and indicate if you modified the licensed material. You do not have permission under this licence to share adapted material derived from this chapter or parts of it.

The images or other third party material in this chapter are included in the chapter's Creative Commons licence, unless indicated otherwise in a credit line to the material. If material is not included in the chapter's Creative Commons licence and your intended use is not permitted by statutory regulation or exceeds the permitted use, you will need to obtain permission directly from the copyright holder.

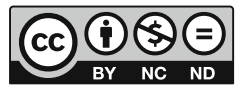

